\title{
Lessons from Joglo's Tectonic Adaptability for Sustainable Future
}

Yenny Gunawan

Department of Architecture, Parahyangan Catholic University, Indonesia

Email: yenny.gunawan@unpar.ac.id

ARTICLE INFORMATION

Received: August 22, 2018

Revised: October 27, 2018

Accepted: December 1, 2018

Published online: January 8, 2019

Keywords:

Joglo, Tectonic, Adaptability, Knock-down.

DOI: http://doi.org/10.15415/cs.2019.62009

\begin{abstract}
In order to accommodate the dynamic human activities, built environments should always be in a constant change. Demolishing, building a new or renovating building are not suitable anymore due to high cost and effort, thus discussions on creating adaptable architecture has increased significantly. This paper suggests that architects can learn from vernacular buildings which already have the capacity to adapt from hundreds years ago. A Javanese vernacular architecture type, known as Joglo, is chosen as case study due to its unique adaptability. Joglo, as a house and pendopo, has existed since the year 1700 s, and it is still reuse until now as gallery, office, café/restaurant, (modern) house, hotel and shops in various locations, even outside Java Island. The analysis is divided into two phases; identifying Joglo's adaptability by dissecting the building components according to Brand's layers to evaluate which part of buildings changes and how much, identifying the relations between buildings' layers and the joints' construction with the aid of a 1:65 scale model to seek a better understanding of six adaptability strategy. In the end, the paper reveal that Joglo's adaptability is deeply influenced by the durability of materials and the knock-down tectonic character. Hopefully, this traditional wisdom of vernacular building can be developed for the creation of sustainable architecture of the future.
\end{abstract}

\section{Introduction}

Buildings can stand for hundreds and even thousands of years, whilst human needs and the environments are in constant changes. To accommodate the dynamic human activities, although buildings seem to be permanent, they are always in constant alterations. The changes can be small such as repainting or refurbishing walls, renewing roofs, but it can also be big such as adding or extending rooms, uplifting the facade even remodelling the whole building. It is interesting to note that with all these alterations, "almost all buildings are designed not to adapt, also budgeted or financed not to, regulated or taxed not to, even remodelled not to" (Brand,1995). Thus, they do not adapt well.

In response to the situation above, many theoreticians and architects are developing and experimenting on adaptable buildings that can changed along with the dynamic of human needs. In this sense, "adaptability can be viewed as a means to decrease the amount of new construction (reduce), (re)activate underused or vacant building stock (reuse) and enhance disassembly/de-construction of components (reuse, recycle) - prolonging the useful life of buildings (reduce, reuse, recycle)" (Schmidt, 2014). As a result, "adaptable buildings are widely recognized as intrinsic to a sustainable built environment" (Kendall and Ando, 2005).
Apart from the architect's experiments, this paper suggests that we should learn adaptability from vernacular buildings which already have been tested over time. From the various definitions of adaptable architecture, this paper identify the understanding of adaptability in relation to "the capacity of a building to accommodate effectively the evolving demands of its context thus maximizing its value through life" (Schmidt, 2014). Although Lellieveld, Voorbij, Poelman(nd.) identified six adaptability schemes, from the most manual to smart technology; flexibility, active, dynamic, interactive, intelligent, smart, but in the context of vernacular buildings, the adaptability definition should be understood in relation to the possibility of adjustments on specific building components with the direct control of users (Lellieveld, Voorbij, Poelman, nd.) manually, without involvement of machines or other type of advance technology.

The chosen case study for the purpose of this study is a type of Javanese vernacular architecture which has existed since 1700s, known as Joglo, due its capacity to adapt until now. Its extraordinary adaptability is apparent through the growing changes in its function from pendopo(shelter) and aristocrats' houses in the old days, (reuse) to modern houses, hotel bungalows and/or lobby, gallery, café/restaurants, office and shops. Apart from the changes in function, Joglo is also reused in many locations, not only in Middle Java 
as its original place, but distributed widely outside Java. In other words, it is portable / movable.

Thus, this paper will unfold the Joglo's adaptability by decomposing or dissecting the building components according to Brand's layers to evaluate which part of building that changes and how much. Furthermore, this paper will identify Joglo's buildings layers' adaptability methods and evaluate them based on six adaptability strategy using a 1:65 model with joints' construction. Lessons from the adaptation of Joglo architecture hopefully can be developed and applied for the creation of a more sustainable built environment, "especially if we defined the word sustainable not only the renewable resources or the continuity of the environment in the realm of technology and economic value, but also as the continuity of a culture" (Gunawan, 2012).

\section{Research Methodology}

Five reused Joglo buildings are selected; showcasing different functions: office (Akanoma architect's studio), café (WarungTaru), bungalow in hotels (Jadul village), (modern) house for a small family of three (father, mother, son), and gallery (Selasar Sunaryo Art Space) (Figure 1) to explain the adaptability of Joglo architecture. All the selected Joglo buildings are relocated from its original place, the relatively flat rural countryside of Middle Java which has a drier and hotter tropical climate, and reconstructed in the hillsides of Bandung, capital city of West Java Province which has a wetter, moister, and colder tropical climate. Four in the northern part and one in the western part of Bandung. From the interviews, these original Joglo buildings age are unknown, but estimated in the year 1700s. The relocation and reconstruction are conducted after the year 2000. It is interesting to note that from the five Joglo buildings, only 2 (two) are designed by architect; the Akanoma architect's studio and bungalow in hotels. The (modern) house is designed by the owner who is an illustrator artist with the help of an architect friend for technical consultation, the other 2 (two) which are the café and gallery, designed by the owner with the help of carpenters.

Although dimensions of the selected building are varied, just like all vernacular buildings' characters, but all Joglo has the same wood frame structural systems, made of teak wood, and building parts. Thus, it is possible to dissect and compare the buildings components according to six Brand's layers (stuff, space plan, services, skin, structure and site) (Figure 2). The layers which can be seen in time frame are (1.) stuff: furniture which can be moved around in days or months; such as chair, desk, lamps, (2.) space plan: the interior layout, incl. walls, ceilings and floors that can be changed in 3 or 30 years, (3.) services: mechanical, electrical and plumbing system which need to be refurbished every 7 to 15 years, (4.) skin: the exterior surface, changed every 20 years to keep up with fashion or technology, (5.) structure: foundation and the load bearing elements which can last from 30 to hundreds or years, the most expensive to replace, and last but not least, (6.) the site: the geographical setting (Brand, 1995 in Gunawan, Y. 2016). The buildings layers comparison will be done by tables and charts, and analyse in relation to which part of buildings changes and why, through interviews with the owners.
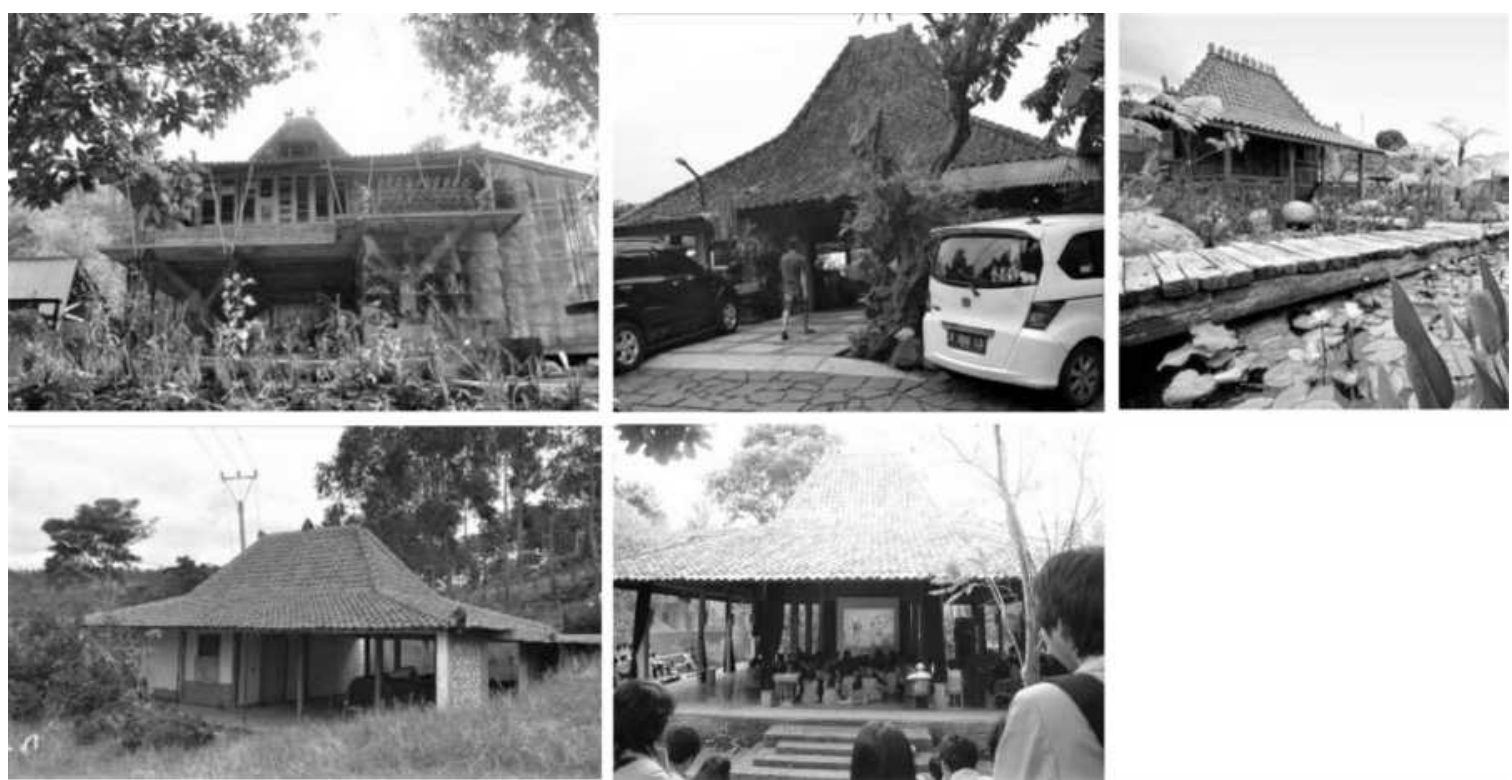

Figure 1. Five case study (above from left to right) Architect's Studio, Café, Hotel Bungalow, (below left) Modern House; and (below right) Gallery.(Source: Author) 
Due to the fact that Joglo is moved, or in other words movable or portable, the second step of the research is identifying adaptability methods and evaluate all case studies' layers based on tectonic character. Tectonic here should be understood in relations to its word origins; tektōn (Greek) means builder, and technikos or techne means art, craft, skill (Webster 2017). Furthermore, this study also highlighted the attention to the construction as the art of joining (Frampton 2001). Thus, the analysis will focuses on relations between buildings' layers and the joints' construction with the aid of a 1:65 scale model to seek a better understanding of six adaptability strategy; adjustable, versatility, refitability, convertible, scalable, and movability (Manewa et.al, 2013, Schmit,2014). This encourages system buildings, standard components, product families, and prefabricated and parallel processes" (Manewa et.al, 2013). The relationships between buildings layers and adaptability strategy can be seen in table 1 based on frequency and type of change (Kelly, 2013, Schmidt, 2009).

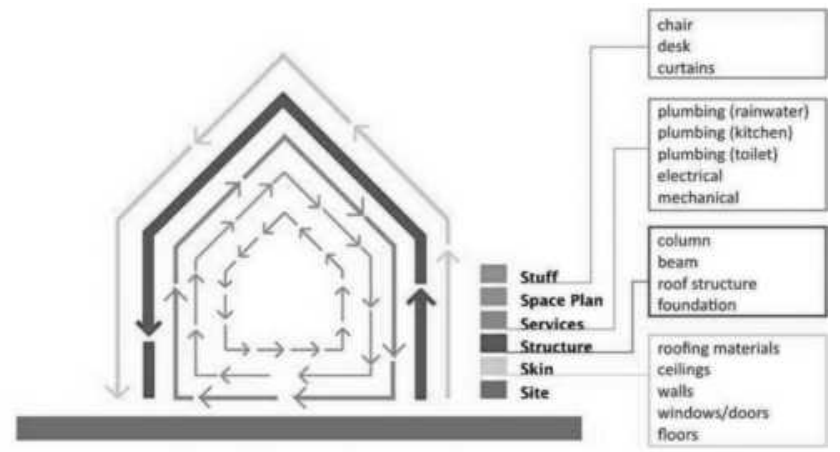

Figure 2. Brands' building layer diagrams with expanded detailed elements. (Source: adapted from Schmidt, 2015)

Table 1. Relationship between buildings layers and adaptability strategy (Source: Kelly, 2013)

\begin{tabular}{lll} 
Strategy & Type of change & Building layer(s) \\
\hline Adjustable & Change of task & Stuff (e.g. furniture, lamps, etc) \\
Versatile & Change of space & Stuff, Space \\
Refitable & Change of & Space, Services, Skin \\
Convertible & performance & Space, Services, Skin \\
Scalable & Change of & Space, Services, Skin, Structure \\
Movable & function & Structure, Site \\
& Change of size & \\
& Change of location & \\
\hline
\end{tabular}

Source: Kelly, 2013

\section{Discussion}

\subsection{Changes in Joglo's Building Layers}

From decomposing or dissecting the Joglo's layers and comparing them, it is found that almost all layers have been changed or altered from the original buildings (stuff, space plan, services, skin, and site -as it is moved from another place-), only the main structural parts (column and beams) and some roofing materials remained from the original Joglo buildings as can be seen in table 2. All the stuffs (furniture) are added new or (some wooden chairs and tables) reused from another old buildings. The space plans are mostly open plan with added kitchen and/or toilet, with the exception of modern house with additional divider for a master bedroom and a walk-in-closet. The services (plumbing, electrical and mechanical) are all new additions adapting to new needs, and all applied different systems depending on the function of the building.

From the interview, the study discovers the various changes of the buildings' skins. All five buildings do not have ceilings, so the structure is visible from the inside. The roofing materials can be originals or new. The walls, windows and doors are mixed; there are original ones, new and/or reused from another old building whether another Joglo type building or another old buildings. The floors are all new arrangements. The various changes happened due to various reasons; from the taste of the owner, the availability of the materials, and the characters of the functions. The structure; column, beam, roof structure, are all originals with some new extensions. But the foundations are all new.

Based on the evaluation of the most original to the least, the order is gallery, café, hotel bungalows, architect's office and the last is modern house (Figure 3). Apparently, this order is related to the daily activities and the nature of the buildings (public versus private buildings). The first two Joglo type buildings are public buildings that accommodate non-daily activities, especially the Joglo type buildings in Selasar Sunaryo Art Space, functioned as a multifunction space and gathering place, only had the addition of curtains, electrical, plumbing, roofing materials and foundations, no walls, door or windows. The café also had two sides of walls, the front facing the street and one side of the buildings, the back opened up to the views. For these functions, no need to add more walls/windows and doors.

Because of the nature of the daily activities, the last three, the hotel bungalow, the architect's studio, and the modern house have enclosed walls in all four sides with variations of the origin and kinds of materials used. In the architect's studio, the Joglo is placed on the second floor supported by four concrete pillars in the first floor. Its walls are mostly reused wooden windows from a dismantled old building (not Joglo type building), while the floors are made from bamboo poles. The first floor is used as a multifunction space and gathering place, whilst the second floor is used as the studio. The hotel bungalow used new wooden planks combined with plastered brick walls for the walls, and reused the doors and windows. And the last (the 
Table 2. Buildings layers' comparison of five case studies with different functions. (Source: Author).

\begin{tabular}{|c|c|c|c|c|c|c|}
\hline \multicolumn{2}{|c|}{$\begin{array}{ll}\text { Building's Layer } & \text { Case Study } \\
\end{array}$} & \multicolumn{2}{|c|}{\begin{tabular}{|ll} 
Office (architect) & Café \\
Studio Akanoma & Warung Taru \\
\end{tabular}} & $\begin{array}{l}\text { Hotel Bungalows } \\
\text { Jadul Village }\end{array}$ & Modern House & $\begin{array}{l}\text { Gallery } \\
\text { Sunaryo Art Space }\end{array}$ \\
\hline$\overline{\text { Stuff }}$ & chair & added new & reused & reused and new & added new & none* \\
\hline & desk & added new & reused & reused and new & added new & none* \\
\hline & curtains & none & none & added new & added new & added new \\
\hline Space Plan & & & added kitchen & added toilet & $\begin{array}{l}\text { added kitchen, toilet } \\
\text { and room. }\end{array}$ & originals \\
\hline \multirow[t]{5}{*}{ Service } & plumbing (rainwater) & added new & added new & added new & added new & added new \\
\hline & plumbing (kitchen) & added new & added new & none & added new & none \\
\hline & plumbing (toilet) & none & none & added new & added new & none \\
\hline & electrical & added new & added new & added new & added new & added new \\
\hline & mechanical & none & none & added new & none & none \\
\hline \multirow[t]{5}{*}{ Skin } & Roofing materials & originals & originals & new & new & new \\
\hline & Ceilings & none & none & none & new & none \\
\hline & Walls & reused and new & new & reused and new & new & none \\
\hline & Windows/Doors & reused and new & reused & reused and new & reused & none \\
\hline & Floors & new & new & new & new & new \\
\hline \multirow[t]{4}{*}{ Structure } & column & $\begin{array}{l}\text { originals } \\
\text { with new extension }\end{array}$ & originals & originals & $\begin{array}{l}\text { originals } \\
\text { with new extension }\end{array}$ & originals \\
\hline & beam & $\begin{array}{l}\text { originals } \\
\text { with new extension }\end{array}$ & $\begin{array}{l}\text { some originals } \\
\text { some reused }\end{array}$ & originals & originals & originals \\
\hline & roof structure & $\begin{array}{l}\text { mixed (originals, new } \\
\text { and reused) }\end{array}$ & originals & $\begin{array}{l}\text { mixed (originals, } \mathrm{n} \\
\text { and reused) }\end{array}$ & new & originals \\
\hline & foundation & new & new & new & new & new \\
\hline Site & Location & $\begin{array}{l}\text { Hill } \\
\text { West Bandung }\end{array}$ & Hill & Hill & Hill & Hill \\
\hline
\end{tabular}

* can be added according to needs.

modern house) is the most private and accommodating daily activities the most, resulting in most changes in the Joglo's buildings parts.

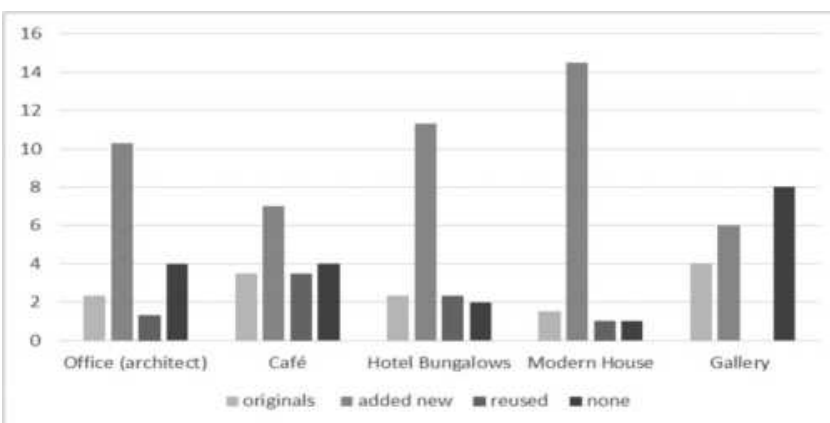

Figure 3. Comparisons of originality of buildings layers between five case studies. (Source : Author).

\subsection{Joglo's Adaptability Strategy}

Apart from the fact that Joglo type buildings can be used for different functions which already demonstrate its ability to change or shift functions (convertible), further analysis of the originality and its close relations to the functions reveal that this order of originality can also be applied to the convertibility with gallery has the ability to shift functions the most (being a multifunctional space with no walls) and the modern house is the least with many dividers. The café and the hotel bungalows have a relatively similar convertibility because both buildings essentially are open spaces with movable furniture.

From the comparative study, because Joglo typle buildings are wood framed made of teak wood with four main pillars in the middle and a specific roof structure and form, it causes centralized organizations. As a result, the expansion or 

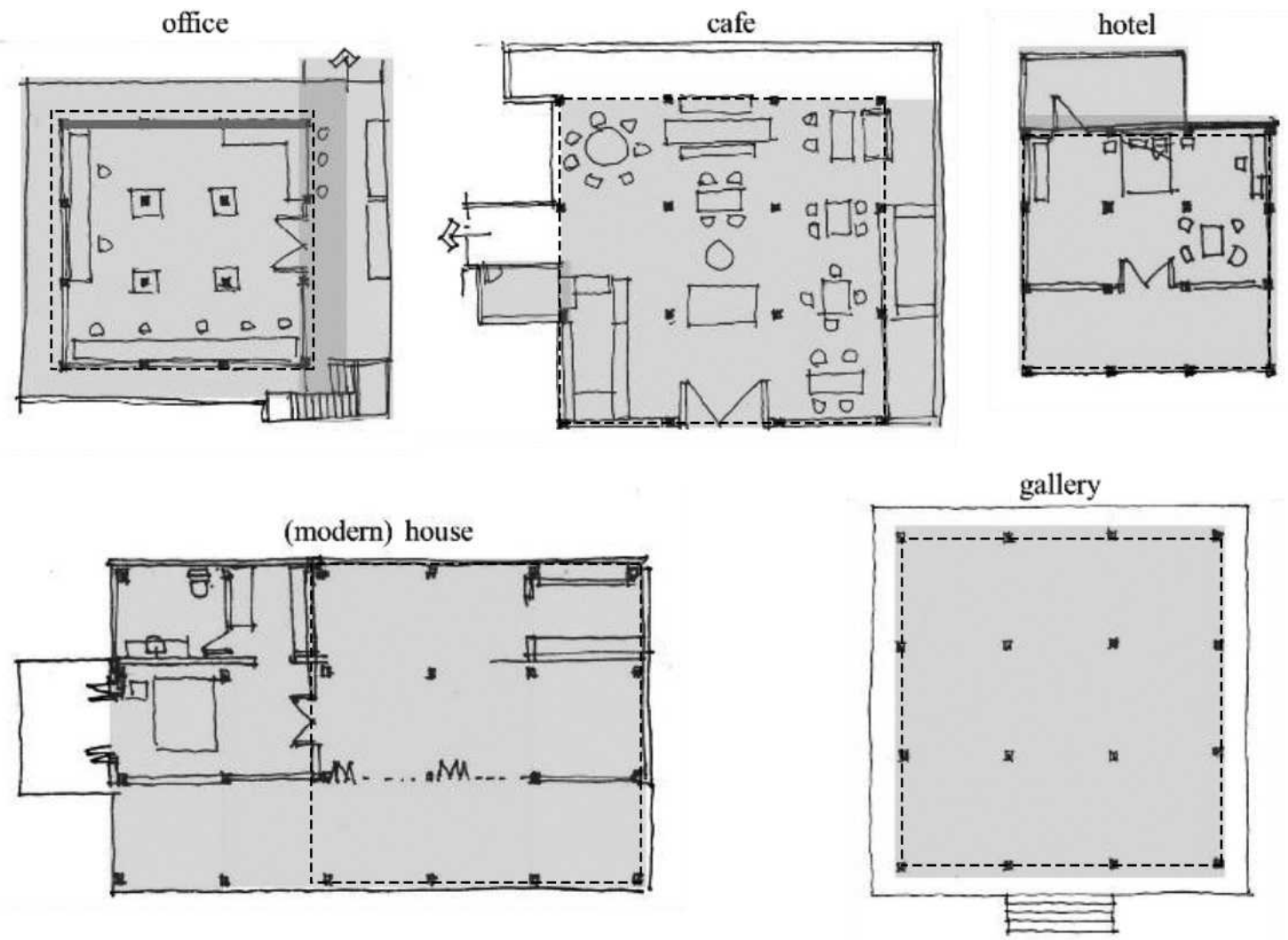

Figure 4. Joglo buildings' original plan (square with dotted line) showcasing expansion in various directions. (Source: Author)

extension (horizontal) are possible in all directions as can be seen in Figure 4 (left, right, back, and also possible front) but limited to a certain point; max. the length between columns. This expandable or extendable adaptability is aligned with scalability (the ability of building to changes size) in the six adaptation strategies. In the architects' studio, as mentioned before, the expansion also happened vertically, the Joglo is placed on the second floor. Interestingly, from the interview, the study find out that when the owners buy Joglo, some of them, especially in the case of modern house, the owner still do not know how it will function as they are now, or in other words, they still do not have the design. The design then evolve after they buy the Joglo type buildings according to its main structural dimensions, and its new site and the skin in this case wooden windows, and doors are reused from another dismantled old buildings, found in the construction processes.

The spatial configurations (shown in Figure 4) also reveal that the structural systems are the basis of Joglo type buildings. This structural systems create an open plan system (except for the toilet) where the non-fixed objects (stuff: adjustable) are placed according to its function, the skins (excluding the floor) are not load bearing and detachable (most façade are made of reused/recycled wooden framed windows/doors), the services' installations are not embedded/ integrated to the main structure, the structures (but the foundations) are wood framed and the site itself change as it is moved from one place to another place (movable). Thus, the skin and the service can be updated, changed, demounted, etc. In this sense, the skin and the service have versatile quality in the adaptability strategy.

Additionally, the interviews reveal that some roofing materials and structural parts sometimes are replaceable depending on the materials conditions and the completeness of the Joglo building's parts when they buy and relocated them. In other words, the structural components (column, beams, and roof structures), the services (electrical, mechanical, plumbing), as well as the skin (roofing materials, walls, doors/windows) can be replaced, changed, renewed and/or reused if some of them are damaged or missing in the dismantling and/or assembling processes (in the case studies, it is mostly the roof structures). This adaptation method is closely related to refitable adaptation strategy. So, in this sense, all five case studies' buildings layers, aside from foundations and floor, demonstrate similar adaptations methods which are adjustable, changeable, replaceable, reusable, recyclable, renewed and movable because they are all detachable or dismantle-able and have knock-down ability (Figure 5). 


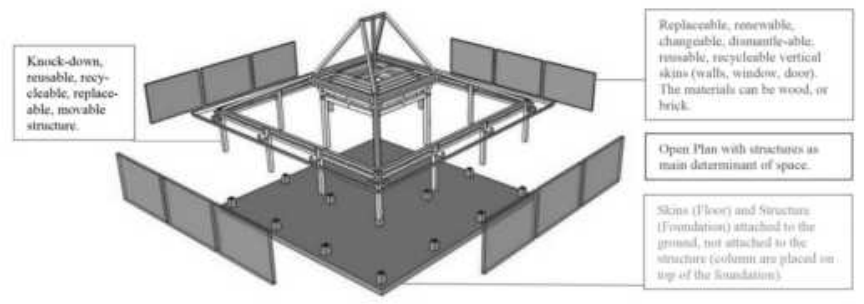

Figure 5. Exploded axonometry showing determinant of Joglo type buildings: the structure. (Source : Author)

This knock-down ability of Joglo's structural systems used two types of wood joint systems in its constructions; the wood lap joint and mortise tenon (Figure 6). The first is used in the beam and beam relations, while the last which is the strongest joint is used in all column-beam connections. Both wood joint systems are strengthen using wooden peg. The wooden columns and foundations made of stone or brick in the olden days and concrete more recently, use mortise and tenon joints' principles; the foundations are perforated $10-20 \mathrm{~cm}$ deep to hold the wood columns. The weight of the wood materials stacked on top of the four main columns in the middle, known as tumpang sari hold the Joglo's column in place.

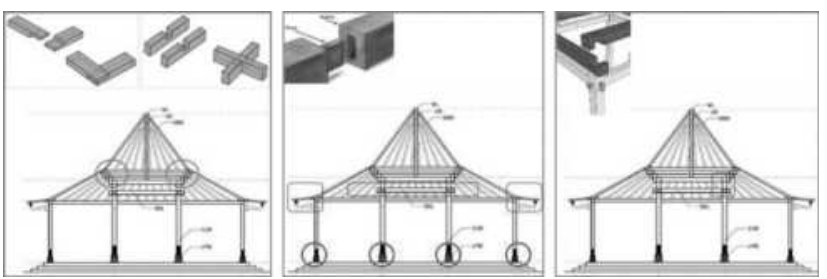

Figure 6. From left to right: lap joint systems of tumpeng sari, mortise-tenon joint of main column and beam, and the lap joint of the main beams. (Source: Author).

Another significant finding is that the two wood joint type mentioned above; lap wood joint and mortise tenon are found in each main pillars in one nodes (Figure 7). So there are 2 types of joints on 1 column's hole causing it to be a 3-dimensional connection with $\mathrm{x}, \mathrm{y}$, and $\mathrm{z}$ axes. Recent study also reveal that this 3 -dimensional connection is identified as one of the things that caused Joglo architecture to withstand earthquakes, in addition to the overall construction and the main structural form of Joglo architecture including tumpang sari as the load. "Wooden structures (eg. soko guru or the main pillars and tumpang sari) are seen as core structures that resist lateral forces, supported by flexibility, stability, elasticity, hyper-static wood and construction. The joint and/or roller joint systems, the mortise tenon connection system, the 4 main pillar's configuration and rigidity with tumpang sari on its top are viewed as the unity of the earthquake responsive building system" (Prihatmaji, 2007).
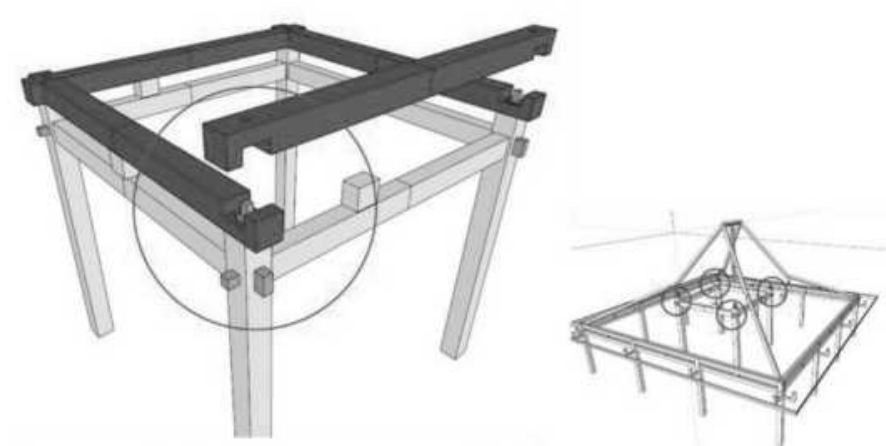

Figure 7. The three dimensional joints in the four main pillars. (Source: Author)

The study proposed that it is these 3 -dimensional connections that enhance the capacity of all Joglo type buildings in the case studies to be knocked down and moved from one place to another. These three-dimensional joints create a unique lock system. The lower beams have two different functions; two beams in parallel are functioned as main beams, and the other two (also in parallel) are the locks (Figure 8) which create dismantle-able and/or knock down ability.
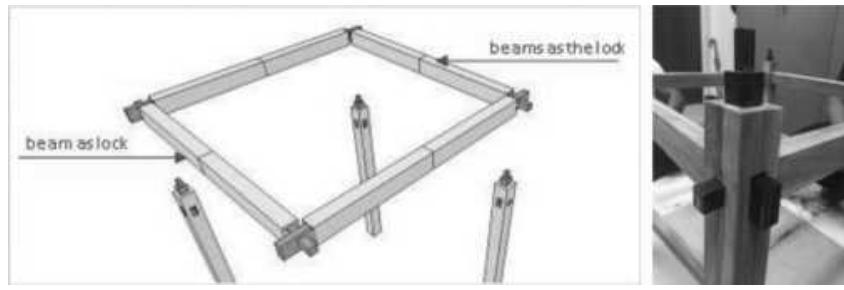

Figure 8. (left) Exploded central main (lower) beams and columns, (right) The connections in a 1:65 scale models. (Source: Author)

From the interviews, Joglo can be knocked-down, packed and moved from the original place in one day by 4 local carpenters. Because of craftmanships, the dimensions of the building parts are not modular, as in many vernacular buildings. Thus, the challenge (based on the 1:65 scale model) is naming and/or coding the building parts when dismantling and assembling, wrong or unclear coding will have resulted in an ineffective time and high effort of constructions. However, if the naming of the parts is correct and clear, then the assembling process is relatively easy. The other drawbacks of the Joglo buildings are the weight of the materials. Teak wood are very heavy, plus dimensions of each parts are usually big. Thus to avoid dangers, the moving of the building parts should be done carefully.

Although the weight of teak wood is undesirable for movability, however, from the interviews, big old teak wood is one of the reason why Joglo type buildings are still used until now. Apart from its durability, older stronger, old big teak wood has become rare, and become more and more expensive. Thus, the owners also buy Joglo type buildings 
for investments. The building can be sold (resale) as it is, or as building parts for other use/functions, such as furniture.

\section{Conclusion}

From the analysis of five case studies, it is apparent that Joglo type buildings can adapt to environmental changes from traditional to modern needs. Six adaptability strategy (Table 3) are made possible due to three things; firstly, its open plan nature (adjustable, versatility, scalable, convertible, refitable), secondly, the detachable system of skin, service and structures (versatile, refitable, convertible, scalable), and its knock-down ability (refitable, convertible, movable) with three dimensional joints and the mortise tenon joint of column and foundation. It can be moved to another place and adapt to new functions. It should be noted that this knock-down ability can be done due to its form as a whole, material durability and economic value. This paper put forward that Joglo's tectonic adaptability can be developed to meet contemporary architecture's needs; the flexible function of space, have economic value, and built from local material and knowledge.

Table 3. Relationship between buildings layers and adaptability strategy. (Source: Author).

\begin{tabular}{ll} 
Building layer(s) & Strategy \\
\hline Stuff (furnitures) & Adjustable, Versatile \\
Space (open plan) & Adjustable, Versatile, Refitable, \\
Services (detachable) & Convertible, Scalable \\
Skin (detachable) & Versatile, Refitable, Convertible \\
Structure (knock- & Versatile, Refitable, Convertible, Scalable \\
down) Site & Refitable, Scalable, Movable Movable \\
\hline
\end{tabular}

\section{Acknowledgements}

Special thanks for Joedith Tjhristianto, Mang Cuncun and Mas Mulyono. Without them, the Joglo's constructions models would not be done correctly. Also, I would like to thank the staff of Research and Community Services Institute, Parahyangan Catholic University for their kind support for this research.

\section{References}

Brand, Steward (1995). How Building Learn: What Happens after They're Built, 2nd ed., Penguin Books, New York.

Cowee, N. P. and Schwehr, P. (2008) Are Our Buildings Fit to Resist Incommensurable Evolution?.Proceedings of $C I B$ World Building Congress. Wellington.

Frampton, Kenneth (2001). Studies in Tectonic Culture, Massachusetts Institute of Technology, USA.

Gunawan, Yenny (2012). Undagi's Sustainable Architecture in Surveys on Vernacular Architecture. Their Significance in the 20th Century Architectural Culture Conference Proceedings. Centro de Estudos Arnaldo Araújo. Oporto.

Kelly, G, Schmidt III, R, Dainty, A and Story , V (2011) Improving the design process for adaptability: Linking feedback and architectural values in Egbu, C. and Lou, E.C.W. (Eds.) Procs 27th Annual ARCOM Conference, 5-7 September, Association of Researchers in Construction Management, Bristol, UK, 43-52.

Kendall, Stephen, and Ando, Masao (2005). Theory and Methods in Support of Adaptable Buildings presented in the 2005 World Sustainable Building Conference, Tokyo, 27-29 September 2005 (SB05Tokyo). Retrieved from http://www.irbnet.de/daten/iconda/ CIB4046.pdf. Accessed 11 August 2016.

Kustianingrum, Wenny. (2009). Penggunaan Arsitektur Tradisional Jawa pada Restoran, unpublished thesis, Fakultas Teknik, Prodi Arsitektur, Universitas Indonesia.

Lelieveld, C.M.J.L., Voorbij, A.I.M., and Poelman, W. A. (n.d.) Adaptable Architecture. Retrieved from http://www.tmu-arch.sakura.ne.jp/pdf/26_proc_ bsa_e/Proceedings_pdf/245-252\%20031SS_B2-2. pdf. Accessed 11 August 2016.

MacManus, Sean Christopher. (2013). Architectural Tectonics: A Shift Between the Cultural Tradition of Making to Contemporary Building Processes, master thesis in architecture, Virginia Polytechnic and State University. USA.

Manewa, A, Pasquire C., Gibb A. Ross, A., and Siriwardena M. (2013) Adaptable Buildings: Striving towards a Sustainable Future. People and Planet 2013 Conference: Transforming the Future, RMIT Univesity, Melbourne, Australia.

Meriam Webster Dictionary Online. https://www. merriam-webster.com/dictionary/tectonic Accessed 30 December 2017.

Prihatmaji, Yulianto P. (2007), Perilaku Rumah Tradisional Jawa "Joglo" terhadap Gempa, Jurnal Dimensi Teknik Arsitektur vol. 35, no. 1, Juli 2007: 1-12, Retrieved from http:/www.petra..ac.id/ mpuslit/journals/dir.php? DepartmentID=ARS. Accessed 13 December 2016.

Prijotomo, Josef (2006). (Re-)Constructing Javanese Architecture: Griya Jawa un-written tradition, Wastu Lanas Grafika, Indonesia.

Schmidt, R. (2014). Designing for Adaptability in Architecture. Doctoral Thesis. Loughborough University. United Kingdom.

Tjahjono, Gunawan (ed.) (1999). Indonesian Heritage (vol. Architecture), Archipelago Press, Heritage Court. 